\title{
Sperm transport and reservoirs in the pig oviduct in relation to the time of ovulation
}

\author{
R. H. F. Hunter \\ School of Agriculture, University of Edinburgh, West Mains Road, Edinburgh EH9 3JG, U.K.
}

\begin{abstract}
Summary. The rate of establishment of a population of viable spermatozoa in the oviducts was studied using a technique of post-coital transection in conjunction with subsequent examination of the proportion of eggs fertilized. Gilts were mated early in oestrus (before ovulation) or on the 2nd day of oestrus (after ovulation), and 30,45 or $60 \mathrm{~min}$ later the reproductive tract was sectioned just above or below the utero-tubal junction in a total of 48 animals; these were slaughtered 1 or 2 days after the operation.

Some fertilized eggs were recovered from 40 animals, and $72.3 \%$ of the 679 eggs examined were fertilized. Mean percentage fertilization increased overall (a) with the time elapsing from mating to transection, (b) with transection below the utero-tubal junction compared with in the caudal isthmus, and (c) with a post-ovulatory versus pre-ovulatory mating. In a further 6 gilts, the results of transection in the lower third of the oviduct $3 \mathrm{~h}$ after mating at the onset of oestrus indicated that spermatozoa were initially sequestered in the caudal portion of the isthmus.

It is concluded that a population of spermatozoa sufficient to give maximum fertilization is established in the oviducts within $1-2 \mathrm{~h}$ of mating, thereby affording protection from the uterine invasion of polymorphonuclear leucocytes.
\end{abstract}

\section{Introduction}

The process of mating and the preliminaries to sperm transport in the reproductive tract of gilts and sows have at least three remarkable features. First, the large volume of semen ejaculated almost directly into the uterus, frequently amounting to $300 \mathrm{ml}$ or more and thereby resulting in distension of the two horns. Second, the disappearance of the bulk of the seminal plasma from the lumen of the uterus within 1-2 h. Third, the oedematous condition of the utero-tubal junction that prevents any gross passage of semen directly into the oviducts of oestrous pigs (reviews by Hunter, 1973, 1975a, b; Polge, 1978). Concerning the last point, three different approaches have suggested that detectable quantities of seminal plasma do not pass beyond the swollen processes of the utero-tubal junction at oestrus (Mann, Polge \& Rowson, 1956; Hunter \& Hall, 1974a; Polge, 1978), but this conclusion has been questioned on the basis of experiments involving insemination of radio-labelled tracer molecules (Einarsson, Jones, Larsson \& Viring, 1980). Apart from interactions of seminal plasma constituents with the utero-tubal junction and possibly also with the musculature of the oviducts, there is the related question of how soon after mating a population of spermatozoa sufficient to ensure fertilization becomes established in the oviducal isthmus. Description of the timing of this process should clarify the means whereby a small proportion of the ejaculated spermatozoa avoids the extensive phase of phagocytosis that is directed at the uterine cellular contents soon after semen deposition (Lovell \& Getty, 1968).

In the following experiments, the technique of post-coital section of the tract has been used to 
study the rate of sperm entry into the oviducts. By performing this intervention at different stages during the prolonged period of oestrus, it has also been possible to confirm the report of du Mesnil du Buisson \& Dauzier (1955a) that there is a more rapid phase of sperm transport close to the time of ovulation than earlier in oestrus.

\section{Materials and Methods}

\section{Animals}

Large White or Large White $\times$ Landrace gilts weighing 98-139 kg and aged 7-9 months were housed and fed in groups of 4-10, and checked for oestrus twice daily with a mature boar. Animals exhibiting oestrus or symptoms of late pro-oestrus were moved to the neighbouring surgical building and penned next to a stud boar. None of the gilts had been used previously for experimental work.

\section{Timing of ovulation}

Ovulation was allowed to occur spontaneously rather than induced in response to injection of hCG during pro-oestrus. The time of mating before or after ovulation could therefore only be estimated, although the anticipated condition of the Graafian follicles or corpora lutea was verified at laparotomy. However, ovulation is known to occur $34 \pm 6 \mathrm{~h}$ after the onset of oestrus (Hammond, 1952; Polge, 1967, 1978; Dziuk, 1973), and so matings performed on the afternoon of the 2 nd day of oestrus were invariably post-ovulatory.

\section{Procedure at mating}

All matings were made by the same boar of proven fertility, gilts being introduced into his pen at the required time and left until a full mating sequence had occurred: this usually involved two complete cycles of ejaculation (see McKenzie, Miller \& Bauguess, 1938). Even so, the duration of mating in this series of experiments did not exceed $9.5 \mathrm{~min}$, after which the gilt was returned to the adjoining pen. She remained in full sight, sound and smell of the boar until the surgical intervention.

\section{Anaesthesia and surgery}

Anaesthesia was induced by intravenous injection of pentobarbitone sodium and maintained by closed-circuit administration of halothane, nitrous oxide and oxygen. Atropine sulphate was not administered to suppress salivation. The reproductive tract was exposed through a mid-ventral incision using aseptic procedures, and the ovaries were briefly examined for mature follicles or recent ovulations without displacing the fimbriae. Double ligatures of No. 2.5 metric gauge silk (Ethicon Ltd), positioned some 2-3 mm apart, were placed around the tract either 2.0 $\mathrm{mm}$ below the utero-tubal junction or in the caudal portion of the isthmus just above this junction (Text-fig. 1). The tissue was transected between the two ligatures with fine-pointed iris scissors, care being taken to avoid damaging the vasculature in the associated mesenteries. The reproductive tract was replaced and the incision closed immediately after transection, and the animals left to recover from the influence of anaesthesia. These manipulations were completed in a total of 48 gilts.

\section{Experimental design}

The main study examined the influence of three variables: (1) gilts were mated either on the morning of the first day of oestrus (i.e. before ovulation) or during the afternoon of the 2 nd day 


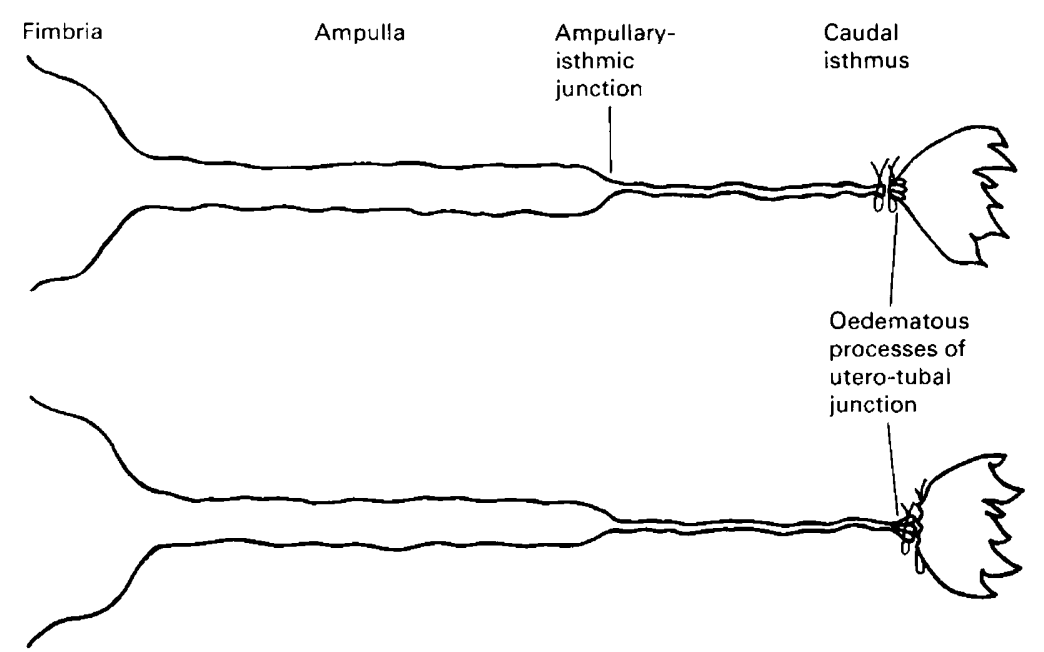

Text-fig. 1. Diagram of the sites of transection of the reproductive tract just above or below the utero-tubal junction in $\mathbf{4 8}$ animals. The thick layer of circular muscle was always evident after sectioning the isthmus whereas the swollen polypoid processes could be seen protruding below the ligature after sectioning the contralateral oviduct.

of oestrus (i.e. after ovulation); (2) the reproductive tract was transected above or below the utero-tubal junction; (3) surgical isolation of the oviducts and/or the utero-tubal junction was performed 30,45 or $60 \pm 5$ min after completion of mating.

In a subsequent experiment performed in 6 gilts mated on the morning of the first day of oestrus, one oviduct was transected one third of the way along the isthmus from the utero-tubal junction whilst the contralateral uterine horn was transected $2.0 \mathrm{~mm}$ below the junction; double ligatures were placed before sectioning the tract $3.0 \mathrm{~h}$ after mating. A final experiment involving 4 gilts compared the influence of transection in the caudal isthmus $2.0 \mathrm{~h}$ after a pre-ovulatory mating with placement and removal of ligatures (i.e. a control procedure) on the contralateral side.

\section{Post-mortem procedures}

Animals were slaughtered at the Edinburgh City abattoir 1 or 2 days after the operation, the reproductive tract was returned to the laboratory, and the contents of each oviduct were flushed with warm Eagle's medium (Flow Laboratories) after removing the ligatures. Whole mounts of the recovered eggs were fixed in $25 \%$ acetic alcohol, stained with $0.5 \%$ orcein in $45 \%$ acetic acid, and examined by phase-contrast microscopy for evidence of sperm penetration and fertilization. The criteria insisted upon included activation of the second meiotic division with extrusion of the second polar body and formation of a female pronucleus together with development of a male pronucleus, or stages subsequent to these.

\section{Statistical analysis}

Differences between treatments were assessed statistically by $\chi^{2}$ analysis.

\section{Results}

Number of oviducts with fertilized eggs

Table 1 shows the number of oviducts containing some fertilized eggs analysed in 48 animals according to the three variables. Fertilization did occur after surgical intervention even when 
transection was performed $30 \mathrm{~min}$ after mating. There was a suggestion that passage of spermatozoa into the oviducts was accelerated when mating was performed after ovulation, again as indicated by the proportion of oviducts containing some fertilized eggs.

Table 1. The proportion of oviducts yielding some fertilized eggs analysed in 48 animals according to the time and location of the transection procedure

\begin{tabular}{|c|c|c|c|c|}
\hline \multirow[b]{3}{*}{$\begin{array}{c}\text { Time of transection after end } \\
\text { of mating } \pm 5 \mathrm{~min}\end{array}$} & \multirow{2}{*}{\multicolumn{2}{|c|}{$\begin{array}{c}\text { Mating on 1st day of oestrus } \\
\text { (i.e. before ovulation) }\end{array}$}} & \multirow{2}{*}{\multicolumn{2}{|c|}{$\begin{array}{c}\text { Mating on 2nd day of oestrus } \\
\text { (i.e. after ovulation) }\end{array}$}} \\
\hline & & & & \\
\hline & $\begin{array}{l}\text { Below utero-tubal } \\
\text { junction }\end{array}$ & In caudal isthmus & $\begin{array}{l}\text { Below utero-tubal } \\
\text { junction }\end{array}$ & In caudal isthmus \\
\hline 30 & $6 / 8$ & $5 / 8$ & $7 / 8$ & $7 / 8$ \\
\hline 45 & $6 / 8$ & $6 / 8$ & $7 / 8$ & $6 / 8$ \\
\hline 60 & $7 / 8$ & $6 / 8$ & $7 / 8$ & $7 / 8$ \\
\hline
\end{tabular}

\section{Number of oviducts with all eggs fertilized}

Table 2 analyses the proportion of oviducts in which all the recovered eggs were fertilized. As would be expected, the proportion of oviducts yielding $100 \%$ fertilization increased with the post-coital interval elapsing before surgery, and matings made after ovulation clearly improved the chances of all eggs being fertilized, irrespective of the site of transection. Furthermore, transections made below the utero-tubal junction resulted in a higher proportion of 'complete fertilizations' compared with transection in the caudal isthmus.

Table 2. The proportion of oviducts yielding maximum fertilization (i.e. $100 \%$ of recovered eggs fertilized) according to the time and location of the transection procedure in 48 animals

\begin{tabular}{|c|c|c|c|c|}
\hline \multirow[b]{3}{*}{$\begin{array}{l}\text { Time of transection after end } \\
\text { of mating } \pm 5 \mathrm{~min}\end{array}$} & \multirow{2}{*}{\multicolumn{2}{|c|}{$\begin{array}{c}\begin{array}{c}\text { Mating on 1st day of oestrus } \\
\text { (i.e. before ovulation) }\end{array} \\
\text { Transection }\end{array}$}} & \multirow{2}{*}{\multicolumn{2}{|c|}{$\begin{array}{c}\begin{array}{c}\text { Mating on 2nd day of oestrus } \\
\text { (i.e. after ovulation) }\end{array} \\
\text { Transection }\end{array}$}} \\
\hline & & & & \\
\hline & $\begin{array}{l}\text { Below utero-tubal } \\
\text { junction }\end{array}$ & In caudal isthmus & $\begin{array}{l}\text { Below utero-tubal } \\
\text { junction }\end{array}$ & In caudal isthmus \\
\hline 30 & $4 / 8$ & $2 / 8$ & $7 / 8$ & $5 / 8$ \\
\hline 45 & $5 / 8$ & $2 / 8$ & $6 / 8$ & $5 / 8$ \\
\hline 60 & $7 / 8$ & $4 / 8$ & $7 / 8$ & $6 / 8$ \\
\hline
\end{tabular}

\section{Proportion of eggs fertilized}

A total of 679 eggs was examined from the 48 animals, of which 491 (72.3\%) were fertilized. In none of the sub-groups were all the recovered eggs fertilized, but attention is drawn to three aspects of the results presented in Table 3. (1) There was an overall increase in the proportion of eggs fertilized with the time elapsing from mating to transection, except eggs recovered from the isthmus isolated after post-ovulatory mating. (2) There was a significant difference $(P<0.05)$ between the proportion of eggs fertilized after a utero-tubal junction versus an isthmus transection at each of the three time intervals, irrespective of whether mating took place before or after ovulation. (3) With the exception of the 60 -min group, there was also a significant increase $(P<0.01)$ in the proportion of fertilized eggs arising from a post-ovulatory versus a pre-ovulatory mating. The mean incidence of fertilization after transection of the isthmus in the 60 -min post-ovulatory group $(62 \cdot 3 \%)$ was depressed through failure to recover any fertilized eggs from 2 animals (a total of 18 unfertilized eggs). 
Table 3. The number of eggs examined and the mean proportions fertilized according to the time and location of the transection procedure in 48 animals

\begin{tabular}{|c|c|c|c|c|c|c|c|c|}
\hline \multirow{4}{*}{$\begin{array}{l}\text { Time of transection after end } \\
\text { of mating } \pm 5 \mathrm{~min}\end{array}$} & \multirow{2}{*}{\multicolumn{4}{|c|}{$\begin{array}{c}\begin{array}{c}\text { Mating on lst day of oestrus } \\
\text { (i.e. before ovulation) }\end{array} \\
\text { Transection }\end{array}$}} & \multirow{2}{*}{\multicolumn{4}{|c|}{$\begin{array}{c}\begin{array}{c}\text { Mating on } 2 \text { nd day of oestrus } \\
\text { (i.e. after ovulation) }\end{array} \\
\text { Transection }\end{array}$}} \\
\hline & & & & & & & & \\
\hline & \multicolumn{2}{|c|}{$\begin{array}{l}\text { Below utero-tubal } \\
\text { junction }\end{array}$} & \multicolumn{2}{|c|}{ In caudal isthmus } & \multicolumn{2}{|c|}{$\begin{array}{l}\text { Below utero-tubal } \\
\text { junction }\end{array}$} & \multicolumn{2}{|c|}{ In caudal isthmus } \\
\hline & $\begin{array}{l}\text { No. of } \\
\text { eggs }\end{array}$ & $\begin{array}{l}\text { \% Ferti- } \\
\text { lization }\end{array}$ & $\begin{array}{l}\text { No. of } \\
\text { eggs }\end{array}$ & $\begin{array}{l}\% \text { Ferti- } \\
\text { lization }\end{array}$ & $\begin{array}{l}\text { No. of } \\
\text { eggs }\end{array}$ & $\begin{array}{l}\% \text { Ferti- } \\
\text { lization }\end{array}$ & $\begin{array}{l}\text { No. of } \\
\text { eggs }\end{array}$ & $\begin{array}{l}\text { \% Ferti- } \\
\text { lization }\end{array}$ \\
\hline 30 & 49 & $75 \cdot 5_{e}^{a}$ & 48 & $45 \cdot 8_{8}^{b}$ & 65 & $89 \cdot 2_{f}^{c}$ & 59 & $72 \cdot 9_{h}^{d}$ \\
\hline 45 & 56 & $69 \cdot 5_{e}^{a}$ & 62 & $46 \cdot 8_{g}^{b}$ & 63 & $81 \cdot 0_{f}^{c}$ & 52 & $73 \cdot 1_{h}^{d}$ \\
\hline 60 & 55 & $85 \cdot 4^{a}$ & 59 & $72 \cdot 9^{b}$ & 50 & $92.0^{c}$ & 61 & $62 \cdot 3^{d}$ \\
\hline
\end{tabular}

Within the horizontal lines, $\chi^{2}$ analysis indicates: $a$ significantly different from $b$ and $c$ significantly different from $d(P<0.05)$; $e$ significantly different from $f$ and $g$ significantly different from $h(P<0.01)$.

\section{Number of spermatozoa per egg}

The number of spermatozoa associated with the zona pellucida was estimated as this membrane gradually dissolved during the staining procedure. When mating occurred early in oestrus, the mean sperm number per egg was usually much greater after transection below the utero-tubal junction compared with transection in the caudal isthmus. In the former group, there were frequently $50-150$ or more spermatozoa per egg whereas the corresponding figures in the latter were of the order of 5-10, except in two instances: here there were 50-70 and in excess of 100 spermatozoa per egg, figures that were common to both sides of the tract. In animals mated after ovulation, by contrast, the numbers were similar on both sides of the tract in 7 of 24 animals, being 50-100 spermatozoa per egg. When eggs were not fertilized, spermatozoa were not located on or in the egg membranes.

Polyspermic fertilization was recorded for 15 eggs (3.1\% of the 491 fertilized eggs), 11 of these occurring after post-ovulatory mating and 7 after transection in the caudal isthmus. Twelve of the 15 eggs were dispermic and three trispermic, these abnormal forms of fertilization being identified at the pronuclear stage. Polyspermic eggs had 50-100 or more spermatozoa associated with the zona pellucida except for one dispermic egg for which there were only 4 spermatozoa in the zona.

A single primary oocyte with a conspicuous germinal vesicle was also recovered (see Hancock, 1961); this presumably atretic egg contained 25-30 spermatozoa in the cortex of the vitellus. The flagellum still seemed to be attached to each sperm head, even though the dimensions of the sperm heads were approximately $50 \%$ larger than those of spermatozoa still outside this egg (see Polge \& Dziuk, 1965).

\section{Persistence of seminal plasma}

Although the uterine horns were not specifically manipulated in order to detect fluid in the lumen, semen was present in the uterus of all animals at laparotomy 30 min after mating whereas this was the case in only 9 of the 16 animals at $60 \mathrm{~min}$. Even so, the uterine horns of 2 animals in the latter group were still distended with fluid, presumably semen. An apparent inequality in the volume of semen distributed between the two uterine horns was common after a post-ovulatory mating, especially when observations were made at 30 and $45 \mathrm{~min}$. In two instances during transection of the uterus at $45 \mathrm{~min}$, a gelatinous plug of seminal origin was displaced from within the folds of the utero-tubal junction. 
A small volume of semen $(<5 \mathrm{ml})$ was detected in the uterus of 2 animals $2.0 \mathrm{~h}$ after mating but none was found in the 6 animals subjected to laparotomy $3.0 \mathrm{~h}$ after mating.

\section{Influence of transection $3.0 \mathrm{~h}$ after mating}

A total of 87 eggs was recovered from the 6 animals in which transection was performed one third of the way along the isthmus some $3.0 \mathrm{~h}$ after completion of mating. This experiment was designed to indicate whether spermatozoa would initially be restricted to the caudal portion of the isthmus after mating early in the pre-ovulatory interval. Two of 44 eggs were fertilized (4.5\%) after transection of the isthmus compared with 41 of 43 (95\%) after a 'control' transection of the contralateral utero-tubal junction. Spermatozoa were not associated with the unfertilized eggs.

\section{Control procedure $2.0 \mathrm{~h}$ after mating}

All 30 eggs recovered from the isthmus isolated $2.0 \mathrm{~h}$ after mating in 4 animals were fertilized, as were 27 of the 28 eggs recovered from the control oviduct; the remaining egg appeared degenerate.

\section{Discussion}

Despite the limitations of an experimental technique involving full anaesthesia and abdominal surgery, the results of this study give a useful indication of the rate of sperm passage into the oviducts after mating. As judged from the procedure of transection in the caudal region of the isthmus, the most important point is that sufficient spermatozoa are already present in the oviducts within 30 min of completion of mating to ensure that a high proportion of the eggs is subsequently fertilized. The increase in the percentage fertilization following transection $60 \mathrm{~min}$ after mating indicates a progressive colonization of the isthmus from sperm reserves in the uterus, and the figures strongly suggest that a population of spermatozoa adequate to promote $100 \%$ fertilization would be established in the oviducts of most gilts within 1-2 $\mathrm{h}$ of mating. This was the situation in 24 of 48 animals after transection of the isthmus 30-60 min after mating and in all 4 animals $2.0 \mathrm{~h}$ after mating, and the results therefore endorse the findings of Burger (1952), First, Short, Peters \& Stratman (1968) and Hunter \& Hall (1974b) on the rate of sperm transport after mating or artificial insemination. Although transport of viable spermatozoa towards the site of fertilization may therefore be appreciably faster in pigs than in certain other species (Leonard, 1950; Adams, 1956; Hancock, 1962; Austin, 1964; Blandau, 1969; Thibault, 1973), the intrauterine site of semen accumulation during mating must be seen as a major contributory factor.

A second point concerning timing of sperm passage into the oviducts is that formation of a reservoir in the isthmus is more rapid after ovulation than early in the period of oestrus when the Graafian follicles may still require another $30-36 \mathrm{~h}$ of maturation before release of the eggs. Whilst animals in the pre-ovulatory groups would have been mated at least $24 \mathrm{~h}$ before ovulation, those classified as post-ovulatory were probably mated within $6-8 \mathrm{~h}$ of completion of ovulation. Many of these animals might, therefore, more reasonably be considered as peri- rather than post-ovulatory, since pigs with a 2-3-day period of oestrus may remain receptive to a boar for 12-24 h after ovulation (Burger, 1952; Ito, Kudo \& Niwa, 1959). Even so, the results confirm the brief reports of du Mesnil du Buisson \& Dauzier (1955a) and Ito et al. (1959) that transport of spermatozoa to the oviducts of pigs is accelerated in the later part of oestrus. In addition, there is good evidence for rabbits (Braden \& Austin, 1954; Turnbull, 1966), hamsters (Yanagimachi \& Chang, 1963), guinea-pigs (Yanagimachi \& Mahi, 1976) and rats (Shalgi \& 
Kraicer, 1978) that sperm transport into or within the oviducts is most rapid close to or just after ovulation; and Battalia \& Yanagimachi (1979) have noted a marked increase in the rate of transport of India ink through the hamster isthmus to the site of fertilization as ovulation approaches. The mechanisms underlying this change in oviducal activity are thought to be programmed by ovarian hormones, possibly mediated in part by a local rather than systemic vascular pathway (see Walsh, Yutrzenka \& Davis, 1979; Hunter, 1980). Specific modifications in the pig could involve not only the muscular and ciliary activity of the oviducts (Gaddum-Rosse \& Blandau, 1973; Blandau \& Gaddum-Rosse, 1974), but also a reduced state of oedema at the utero-tubal junction and in the longitudinal folds of the isthmus, permitting a greater permeability to sperm passage as ovulation approaches (Hunter, 1972, 1973). Because the swollen condition of these structures in pre-ovulatory pigs can be reduced by local microinjections of progesterone in oil (Hunter, 1972), pre-ovulatory secretion of progesterone by the Graafian follicles may be involved in the physiological regulation of this change (Hunter, Hall, Cook \& Taylor, 1972).

As judged from the subsidiary experiment involving 6 gilts, spermatozoa accumulate and are largely sequestered in the lowermost few centimetres of the isthmus in the early part of oestrus. This phase of sperm storage again indicates some co-ordination between release of eggs from the follicles and a redistribution of spermatozoa from the constricted lumen of the isthmus. Our findings suggest that the redistribution of spermatozoa near the time of ovulation is an active physiological process and not simply a reflection of the time required for spermatozoa to reach the site of fertilization at the ampullary-isthmic junction. Specific support for this contention comes from the study of Hunter \& Dziuk (1968) in which insemination of gilts at the time of ovulation led to fertilization of $41 \%$ of 104 eggs within $3 \mathrm{~h}$ of semen deposition, this being the same interval as from mating to transection one third of the way along the isthmus in the present work when $<5 \%$ of eggs were fertilized. This reservoir role of the isthmus in the pre-ovulatory interval is not peculiar to the pig, for the studies of Harper (1973a, b) using the technique of egg transplantation first indicated the occurrence of such a phenomenon in the rabbit, for which species it has since been examined and discussed in some detail (Overstreet \& Cooper, 1978, 1979). Depression of sperm motility may be an important feature of the isthmic reservoir (Overstreet, Katz \& Johnson, 1980).

Although our observations lack precision, there would seem to be a good relationship between the gross disappearance of seminal plasma from the uterine cornua and the establishment of adequate sperm reservoirs in each isthmus. Lovell \& Getty (1968) could only find residual foaming moisture in the uterus $1 \frac{3}{4} \mathrm{~h}$ after service, and Rigby (1964) could not recover significant amounts of fluid from the uterus $2 \mathrm{~h}$ after mating or insemination, results that correspond closely with the earlier report of du Mesnil du Buisson \& Dauzier (1955b). Because of the oedematous barrier formed by the processes of the utero-tubal junction during oestrus, and hence the severe limitation on access to the lumen of the oviducts, a high concentration of spermatozoa must be present on the uterine side of this region for a time sufficient to enable formation of adequate sperm reservoirs (Hunter, 1973, 1975b; indeed, this appears to be the overriding function of the voluminous boar ejaculate, and would accord with the conclusions of Rigby (1964) and Baker, Dziuk \& Norton (1968) that the number of spermatozoa entering the pig oviduct is dependent on the concentration of spermatozoa in the inseminate. The site of the initial sperm reservoir was reported to be within the folds and diverticula of the utero-tubal junction (Rigby, 1964, 1966; Baker et al., 1968), but the isthmus progressively assumes this role (du Mesnil du Buisson \& Dauzier, 1955b; Hunter \& Léglise, 1971) to become the functional reservoir at the time of ovulation-as also inferred from the present results.

The precise manner whereby spermatozoa negotiate the utero-tubal junction to enter the isthmus of oestrous animals remains to be demonstrated, especially during the pre-ovulatory interval, although the use of scanning electron microscopy has clarified some of the morphological relationships (Fléchon \& Hunter, 1981). But on the basis of the timing recorded 
in this study and in the work of Rigby (1966), a good case could be made for sperm motility and ciliary activity being more important than that of myometrial and myosalpingeal contractions. Any major involvement of muscular activity at the utero-tubal junction would be expected to promote an even more rapid and quantitatively significant transport of spermatozoa into the oviducts together with other cell types suspended in uterine fluids. Even though dead spermatozoa can apparently be transported into the oviducts of oestrous pigs under certain experimental conditions (First et al., 1968; Baker \& Degen, 1972), there is no evidence for the presence of polymorphonuclear leucocytes in the oviducal lumen in the pre-ovulatory interval (Hunter, 1973; Fléchon \& Hunter, 1981) nor would it seem biologically appropriate for polymorphs to gain the site of the functional sperm reservoir before ovulation. As to the question of whether boar seminal plasma enters the oviducts after mating, the situation may change during the period of oestrus. The use of biochemical (Mann et al., 1956), physiological (Hunter \& Hall, 1974a) and radio-opaque methods (Polge, 1978) suggested that detectable amounts of seminal plasma do not enter the oviducts at oestrus. On the other hand, the study of Einarsson $e t a l$. (1980) using radio-labelled compounds suspended in boar seminal plasma indicated the presence of radioactivity in oviduct tissues $1 \mathrm{~h}$ after insemination on the 2 nd day of oestrus. Whether the activity was actually in the lumen, as distinct from the wall of the oviduct, could not be specified, nor was it known if the route of transfer might have involved the lymphatic supply. Nonetheless, the polypoid processes of the utero-tubal junction and the folds of the isthmus do become less oedematous in late oestrus (Andersen, 1928; Lee, 1928), so the chances of seminal plasma entering the oviducts would presumably increase, although too late to influence the process of fertilization.

This study was supported in part by a grant from the Agricultural Research Council, for which grateful acknowledgement is made. I also thank Mr R. Nichol for technical assistance and Dr I. Wilmut for comments on a draft of the manuscript.

\section{References}

Adams, C.E. (1956) A study of fertilization in the rabbit: the effect of post-coital ligation of the Fallopian tube or uterine horn. J. Endocr. 13, 296-308.

Andersen, D.H. (1928) Comparative anatomy of the tubo-uterine junction. Histology and physiology in the sow. Am.J. Anat. 42, 255-305.

Austin, C.R. (1964) Behaviour of spermatozoa in the female genital tract and in fertilization. Proc. 5th Int. Congr. Anim. Reprod. Trento 3, 7-22.

Baker, R.D. \& Degen, A.A. (1972) Transport of live and dead boar spermatozoa within the reproductive tract of gilts. J. Reprod. Fert. 28, 369-377.

Baker, R.D., Dziuk, P.J. \& Norton, H.W. (1968) Effect of volume of semen, number of sperm and drugs on transport of sperm in artificially inseminated gilts. $J$. Anim. Sci. 27, 88-93.

Battalia, D.E. \& Yanagimachi, R. (1979) Enhanced and co-ordinated movement of the hamster oviduct during the periovulatory period. J. Reprod. Fert. 56, 515-520.

Blandau, R.J. (1969) Gamete transport-comparative aspects. In The Mammalian Oviduct, pp. 129-162. Eds E. S. E. Hafez \& R. J. Blandau. University of Chicago Press.

Blandau, RJ. \& Gaddum-Rosse, P. (1974) Mechanism of sperm transport in pig oviducts. Fert. Steril. 25, 61-67.
Braden, A.W.H. \& Austin, C.R. (1954) The number of sperms about the eggs in mammals and its significance for normal fertilisation. A ust. J. biol. Sci. 7, 543-551.

Burger, J.F. (1952) Sex physiology of pigs. Onderstepoort J. vet Res., Suppl. No. 2.

du Mesnil du Buisson, F. \& Dauzier, L. (1955a) La remontée des spermatozoides du verrat dans le tractus génital de la truie en oestrus. C. r. Séanc. Soc. Biol. 149, 76-79.

du Mesnil du Buisson, F. \& Dauzier, L. (1955b) Distribution et résorption du sperme dans le tractus génital de la truie: survie des spermatozoides. Annls Endocr. 16, 413-422.

Dziuk, P.J. (1973) Occurrence, control and induction of ovulation in pigs, sheep and cows. In Handbook of Physiology, Section 7, Endocrinology II, Part 1, pp. 143-152. Eds R. O. Greep \& E. B. Astwood. Am. Physiol. Soc., Washington, D.C.

Einarsson, S., Jones, B., Larsson, K. \& Viring, S. (1980) Distribution of small- and medium-sized molecules within the genital tract of artificially inseminated gilts. J. Reprod. Fert. 59, 453-457.

First, N.L., Short, R.E., Peters, J.B. \& Stratman, F.W. (1968) Transport of boar spermatozoa in estrual and luteal sows. J. Anim. Sci. 27, 1032-1036.

Fléchon, J.E. \& Hunter, R.H.F. (1981) Regulation of 
sperm transport by the utero-tubal junction and isthmus in pigs: a scanning electron microscope study. Tissue \& Cell 13, 127-139.

Gaddum-Rosse, P. \& Blandau, R.J. (1973) In vitro studies on ciliary activity within the oviducts of the rabbit and pig. Am.J. Anat. 136, 91-104.

Hammond, J. (1952) Farm Animals: their Breeding, Growth and Inheritance, 3rd edn. Edward Arnold Ltd, London.

Hancock, J.L. (1961) Fertilization in the pig. J. Reprod. Fert. 2, 307-331.

Hancock, J.L. (1962) Fertilization in farm animals. Anim. Breed. Abstr. 30, 285-310.

Harper, M.J.K. (1973a) Stimulation of sperm movement from the isthmus to the site of fertilisation in the rabbit oviduct. Biol. Reprod. 8, 369-377.

Harper, M.J.K. (1973b) Relationship between sperm transport and penetration of eggs in the rabbit oviduct. Biol. Reprod. 8, 441-450.

Hunter, R.H.F. (1972) Local action of progesterone leading to polyspermic fertilization in pigs. J. Reprod. Fert. 31, 433-444.

Hunter, R.H.F. (1973) Transport, migration and survival of spermatozoa in the female genital tract: species with intra-uterine deposition of semen. In Sperm Transport, Survival and Fertilizing Ability, pp. 309-342. Eds E. S. E. Hafez \& C. Thibault. INSERM, Paris.

Hunter, R.H.F, (1975a) Physiological aspects of sperm transport in the domestic pig, Sus scrofa. I. Semen deposition and cell transport. Br. vet. J. 131, $565-573$.

Hunter, R.H.F. (1975b) Physiological aspects of sperm transport in the domestic pig, Sus scrofa. II. Regulation, survival and fate of cells. Br. vet. J. 131, $681-690$.

Hunter, R.H.F. (1980) Transport and storage of spermatozoa in the female tract. Proc. 9th Int. Congr. Anim. Reprod. \& A.I. Madrid 2, 227-233.

Hunter, R.H.F. \& Dziuk, P.J. (1968) Sperm penetration of pig eggs in relation to the timing of ovulation and insemination. J. Reprod. Fert. 15, 199-208.

Hunter, R.H.F. \& Hall, J.P. (1974a) Capacitation of boar spermatozoa: synergism between uterine and tubal environments. J. exp. Zool. 188, 203-214.

Hunter, R.H.F. \& Hall, J.P. (1974b) Capacitation of boar spermatozoa: the influence of post-coital separation of the uterus and Fallopian tubes. Anat. Rec. 180, 597-604.

Hunter, R.H.F. \& Léglise, P.C. (1971) Polyspermic fertilization following tubal surgery in pigs, with particular reference to the rôle of the isthmus. $J$. Reprod. Fert. 24, 233-246.

Hunter, R.H.F., Hall, J.P., Cook, B. \& Taylor, P.D. (1972) Oestrogens and progesterone in porcine peripheral plasma before and after induced ovulation. J. Reprod. Fert. 31, 499-501.

Ito, S., Kudo, A. \& Niwa, T. (1959) Studies on the normal oestrus in swine with special reference to proper time for service. Annls Zootech., Ser. D., Suppl. pp. 105-107.
Lee, F.C. (1928) The tubo-uterine junction in various animals. Bull. Johns Hopkins Hosp. 42, 335-357.

Leonard, S.L. (1950) The reduction of uterine sperm and uterine fluid on fertilization of rat ova. Anat. Rec. 106, 607.

Lovell, J.E. \& Getty, R. (1968) Fate of semen in the uterus of the sow: histologic study of endometrium during the 27 hours after natural service. Am.J. vet. Res, 29, 609-625.

Mann, T., Polge, C. \& Rowson, L.E.A. (1956) Participation of seminal plasma during the passage of spermatozoa in the female reproductive tract of the pig and horse. J. Endocr. 13, 133-140.

McKenzie, F.F., Miller, J.C. \& Bauguess, L.C. (1938) The reproductive organs and semen of the boar. Res. Bull. Mo. Agric. Exp. Stn, No. 279.

Overstreet, J.W. \& Cooper, G.W. (1978) Sperm transport in the reproductive tract of the female rabbit. $I$. The rapid transit phase of transport. Biol. Reprod. 19, 101-114.

Overstreet, J.W. \& Cooper, G.W. (1979) Effect of ovulation and sperm motility on the migration of rabbit spermatozoa to the site of fertilization. $J$. Reprod. Fert. 55, 53-59.

Overstreet, J.W., Katz, D.F. \& Johnson, L.L. (1980) Motility of rabbit spermatozoa in the secretions of the oviduct. Biol. Reprod. 22, 1083-1088.

Polge, C. (1967) Control of ovulation in pigs. Proc. $\boldsymbol{R}$. Soc. Med. 60, 654-655.

Polge, C. (1978) Fertilization in the pig and horse. $J$. Reprod. Fert. 54, 461-470.

Polge, C. \& Dxiuk, P. (1965) Recovery of immature eggs penetrated by spermatozoa following induced ovulation in the pig. J. Reprod. Fert. 9, 357-358.

Rigby, J.P. (1964) The fate of spermatozoa in the genital tract of the sow following artificial insemination. Proc. 5th Int. Congr. Anim. Reprod. \& A.I. Trento 4, $421-425$.

Rigby, J.P. (1966) The persistence of spermatozoa at the uterotubal junction of the sow. J. Reprod. Fert. 11, 153-155.

Shalgi, R. \& Kraicer, P.F. (1978) Timing of sperm transport, sperm penetration and cleavage in the rat. J. exp. Zool. 204, 353-360.

Thibault, C. (1973) Sperm transport and storage in vertebrates. J. Reprod. Fert., Suppl. 18, 39-53.

Turnbull, K.E. (1966) The transport of spermatozoa in the rabbit doe before and after ovulation. A ust. $J$. biol. Sci. 19, 1095-1099.

Walsh, S.W., Yutrzenka, G.J. \& Davis, J.S. (1979) Local steroid concentrating mechanism in the reproductive vasculature of the ewe. Biol. Reprod. 20, 1167-1171.

Yanagimachi, R. \& Chang, M.C. (1963) Sperm ascent through the oviduct of the hamster and rabbit in relation to the time of ovulation. J. Reprod. Fert. 6, $413-420$.

Yanagimachi, R. \& Mahi, C.A. (1976) The sperm acrosome reaction and fertilization in the guinea-pig: a study in vivo. J. Reprod. Fert. 46, 49-54.

Received 22 October 1980 